\title{
Odpowiedź profesorowi Andrzejowi Żbikowskiemu
}

\section{A Response to Professor Andrzej Żbikowski}

Na wstępie pragnę wyrazić wdzięczność profesorowi Andrzejowi Żbikowskiemu za wyważoną i mądrą recenzję mojej książki Polskie Państwo Podziemne i Żydzi w czasie II wojny światowej. Materiały związane z tym projektem zacząłem gromadzić w roku akademickim 2004-2005 w trakcie badań archiwalnych prowadzonych wtedy przeze mnie w Polsce i w Anglii. Złożoność tej problematyki, jej delikatna natura jako punktu głębokiego sporu w relacjach polsko-żydowskich, konieczność wyszukania i zrozumienia dokumentów, a także liczne podróże, by spotkać się z żydowskimi i nieżydowskimi członkami Armii Krajowej - wszystkie te czynniki sprawiły, że wstępną wersję książki ukończyłem dopiero w styczniu 2014 roku. W latach 2004-2014 ukazało się wiele prac naukowych, zwłaszcza w Polsce, dzięki badaczom związanym z nowo utworzonym Centrum Badań nad Zagładą Żydów. Zresztą właśnie podczas badań w Polsce w latach 2004-2005 poznałem Adama Puławskiego i Dariusza Libionkę, z którymi spotykam się w archiwach i na rozmaitych forach naukowych. W tamtym okresie, w 2004 roku, literatura przedmiotu miała wyłącznie charakter polemiczny i odzwierciedlała podział na dwa wzajemnie wykluczające się obozy: tych (głównie Żydów), którzy uważali polskie podziemie za endemicznie antysemickie, i tych (przede wszystkim Polaków), którzy opisywali polskie podziemie jako demokratyczne, prawe i heroiczne - jako męczenników wolności i demokracji.

Warto zauważyć, że najważniejsze prace poświęcone tej tematyce, powstałe jeszcze w XX wieku, zgromadziły sporo dokumentów potwierdzających któreś z wspomnianych wyżej przeciwstawnych stanowisk. Mieliśmy więc na przykład książkę Shmuela Krakowskiego i Israela Gutmana pt.: Unequal Victims: Poles and Jews during World War Two (1986), prezentującą wiele dokumentów potwierdzających zbrodnie na Żydach dokonywane przez Armię Krajową, a z drugiej strony publikację Władysława Bartoszewskiego i Zofii Lewinówny Ten jest z ojczyzny mojej (1966), która prezentowała dokumenty zaświadczające 
o pomocy i sympatii polskiego podziemia dla ludności żydowskiej. Można było wręcz odnieść wrażenie, że istniały dwa polskie podziemia: prawe i demokratyczne, wykorzystujące każdą sposobność do pomocy Żydom, oraz żydożercze, pragnące wyzyskiwać, denuncjować i mordować Żydów przy każdej nadarzającej się okazji. Wziąłem na siebie zadanie dokonania ponownego przeglądu tej tematyki (opartego na nowych badaniach archiwalnych i ocenie dokumentów publikowanych przez obydwa obozy) i stworzenia wyważonego, bezstronnego studium, którego wnioski formułowane były wyłącznie na podstawie dostępnych świadectw.

Profesor Żbikowski, wybitny badacz i autor wielu publikacji poświęconych relacjom polsko-żydowskim podczas II wojny światowej, który doskonale zna problematykę postaw i działań polskiego podziemia wobec Żydów, na początku swojej recenzji wskazuje, że książka będąca podstawą polskiego przekładu została napisana po angielsku i była adresowana do czytelnika angielskojęzycznego. To prawda, że pisząc w tym języku, musiałem obszernie zaprezentować te materiały, które w Polsce są doskonale znane, a zatem w polskiej edycji mogłyby one zostać jedynie ogólnie omówione. Zgadzam się, że można było skrócić dużą część materiału wprowadzającego, uważam jednak zarazem, że podanie pewnych elementów tła historycznego jest niezbędne również w przypadku czytelnika polskiego. Dotyczy to na przykład przeglądu pięciu przedwojennych partii opozycyjnych i ich oficjalnych stanowisk dotyczących Żydów i kwestii żydowskiej, ogłaszanych w latach 1936-1939, a także omówienia politycznej struktury Polskiego Państwa Podziemnego i rządu emigracyjnego w latach 1939-1940. Fakt, iż strukturę tę współtworzyło z jednej strony zaciekle antysemickie Stronnictwo Narodowe (SN), a z drugiej dwie partie jednoznacznie i konsekwentnie sprzeciwiające się antysemityzmowi - Polska Partia Socjalistyczna (PPS) i Stronnictwo Demokratyczne (SD) - jest moim zdaniem kluczem do zrozumienia postaw i działań polskiego podziemia, które było, jak twierdzę w mojej książce, zarówno antyżydowskie, jak i prożydowskie. Nie jestem pewien, czy zasadne jest założenie, że wszyscy polscy czytelnicy dostatecznie znają ten aspekt politycznego tła omawianych wydarzeń.

Żbikowski podkreśla, że i ja, i polscy badacze tacy jak Adam Puławski, korzystamy generalnie z tych samych źródeł. Zgodnie wskazujemy, iż jest to historia zarówno zbrodni przeciw Żydom, jak i udzielanej im pomocy. Zdaniem recenzenta różni nas to, że ja jestem skłonny podkreślać pozytywy. Cieszę się, że Żbikowski przywołuje wstęp, w którym wyjaśniam, że kiedy zacząłem rozważać podjęcie badań związanych z tą tematyką, literatura przedmiotu autorstwa historyków amerykańskich, izraelskich i zachodnioeuropejskich była całkowicie negatywna i w gruncie rzeczy broniła tezy, że Armia Krajowa przejawiała postawy zaciekle antysemickie i w żadnych okolicznościach nie można było liczyć na jej pomoc lub zrozumienie. Kiedy więc w trakcie badań ustaliłem, że istniały instytucje Polskiego Państwa Podziemnego powołane do pomocy Żydom, takie jak Żegota (Rada Pomocy Żydom przy Delegaturze Rządu 
RP na Kraj) czy Referat Żydowski Komendy Głównej Armii Krajowej, czułem się w obowiązku zaprezentować angielskojęzycznym czytelnikom te przypadki podważające przyjmowane powszechnie stanowisko. Z kolei w Polsce wielu historyków uznało, że ich powinnością jest przedstawić polskiemu czytelnikowi liczne zbrodnie przeciw Żydom dokonywane przez członków Armii Krajowej, które do końca XX wieku były nieobecne w polskiej literaturze naukowej i popularnonaukowej.

Jeden z wątków recenzji Żbikowskiego dotyczy dwóch odmiennych podejść do pisarstwa historycznego. Zauważa on, że nie krytykuję Armii Krajowej za to, jak pokazywała zagładę Żydów w wydawanej przez siebie prasie. Żbikowski odnosi się do częstej praktyki ukrywania doniesień o masakrach Żydów w lakonicznej kronice wydarzeń umieszczanej na końcu numeru. Moim celem było bezstronne przedstawienie wszystkich istniejących świadectw, tak by czytelnik mógł sam wyciągnąć wnioski. Zamiast więc instruować czytelnika, jak ma interpretować relacje prasowe, wykorzystywałem fotokopie oryginalnych materiałów, zawsze ze wskazaniem strony. Kiedy w numerze z 19 lutego 1942 roku „Biuletyn Informacyjny” po raz pierwszy doniósł o wykorzystaniu trującego gazu do zamordowania Żydów w Chełmnie, relacja pojawiła się na stronie 9. Moim zdaniem nie było konieczne wyjaśnienie czytelnikowi, że redakcyjna decyzja o zamieszczeniu szokującej informacji na ostatniej, a nie na pierwszej stronie jest znacząca i jako taka powinna stać się przedmiotem szczególnego namysłu. Dla czytelników angielskojęzycznych znających książkę Debory Lipstadt pt.: Beyond Belief: the American Press and the Coming of the Holocaust, 1933-1945 (1986), w której wskazuje się, że nawet w „New York Timesie" relacje o masowych mordach Żydów często umieszczano na środkowych, a także końcowych stronach numeru, odkrycie, że podobna sytuacja zaistniała w polskiej prasie podziemnej, nie będzie niczym szokującym.

Jeśli chodzi o szmalcownictwo, profesor Żbikowski słusznie zaznacza, że polskie podziemie pociągnęło do odpowiedzialności jedynie kilku Polaków winnych uprawiania tego procederu. Zastanawia się zatem nad zasadnością podkreślania tych przypadków w sytuacji, gdy było ich tak niewiele. Różnica między moim podejściem do kwestii szmalcownictwa a sposobem przedstawiania go przez polskich badaczy wynika stąd, że nasze prace powstawały w radykalnie odmiennym otoczeniu. W świecie anglojęzycznym, gdzie często jedynym komentarzem na temat Armii Krajowej, jaki można znaleźć w literaturze naukowej, jest uwaga o jej antysemityzmie, sam fakt, że polskie podziemie nie tylko otwarcie potępiało szmalcowników, lecz także dokonywało ich egzekucji, informując o tym następnie na pierwszych stronach swoich najważniejszych czasopism, na tyle przeciwstawia się dominującemu poglądowi o antysemityzmie całego polskiego podziemia, że konieczność zdecydowanego uwydatnienia tego aspektu wydała mi się oczywista. Niezwykle godne pochwały jest to, że Żbikowski i wielu innych polskich badaczy podkreślają dziś, iż to było po prostu za mało - że za swe zbrodnie powinna zapłacić znacznie większa liczba 
Polaków. To oczywiście prawda. Niemniej jednak w sytuacji, gdy jedyna informacja na temat Armii Krajowej, jaką dostają czytelnicy podręczników dla wyższych uczelni, takich jak Holocaust: A History (2002) Debory Dwork i Roberta Jana van Pelta, jest taka, że była ona „poddawana represjom, patriotyczna i głęboko uprzedzona do Żydów", należało zaproponować pełniejszy obraz przeszłości, tak by nie była ona już wypaczana.

Chciałbym przy tej okazji dokonać pewnego sprostowania. W nawiązaniu do strat poniesionych przez Niemców podczas powstania w getcie warszawskim Żbikowski wskazuje, że podaję zawyżone dane dotyczące zabitych i rannych, opierając się na relacjach prasy Armii Krajowej. Pisze: „Co zaskakujące, przytaczając przesadzone raporty warszawskiego AK o licznych zabitych Niemcach, nie zestawia ich $\mathrm{z}$ informacjami zawartymi w raporcie Jürgena Stroopa, który podaje dane rzeczywiste". Zgodziłbym się z tą opinią, gdyby nie następująca uwaga, którą można znaleźć w mojej książce:

Szacunki dotyczące niemieckich strat $\mathrm{w}$ czasie powstania w getcie warszawskim wahają się od 86 zabitych i 420 rannych (ocena Polskiego Państwa Podziemnego z maja 1943) po dane z oficjalnego raportu Stroopa, w którym stwierdza on, że zginęło 16 Niemców, a 85 zostało rannych. Wydaje się, że rzeczywista liczba kształtuje się gdzieś między tymi dwoma szacunkami (s. 317, przyp. 92).

Jeśli chodzi o kwestię stosunku polskiego podziemia do powstania w getcie warszawskim, Żbikowski uznaje moją ocenę za w gruncie rzeczy pozytywną. Chciałbym dodać drobny komentarz. Uznałem, że pisząc dla czytelnika angielskojęzycznego, który przyjmuje, że polskie podziemie odwróciło się do Żydów plecami i nie udzieliło im żadnej pomocy, powinienem starannie odnotować wszystkie potwierdzone przypadki pomocy dla warszawskiego getta podczas powstania, aby wypełnić luki w wiedzy i zakwestionować zbiorową pamięć Żydów, zgodnie z którą żadna tego rodzaju pomoc nie występowała. Fakt, iż 19 kwietnia 1943 roku dwaj osiemnastoletni żołnierze Armii Krajowej, Józef Wilk i Eugeniusz Morawski, zginęli, a pięciu innych zostało rannych podczas misji, której celem było wysadzenie murów getta, co miało umożliwić masową ucieczkę, jest moim zdaniem niezwykle znaczącym odkryciem dla angielskojęzycznych czytelników, jeśli weźmiemy pod uwagę, że poza granicami Polski dominuje przekonanie o braku jakiejkolwiek pomocy dla powstania.

Podsumowując, pragnę podziękować prof. Żbikowskiemu za cenne uwagi, a zwłaszcza za stwierdzenie, iż „W sumie otrzymaliśmy bardzo osobistą książkę na ważny dziś i szeroko komentowany temat. Fakt ten oceniam bardzo pozytywnie, licząc na jej szeroki odzew i nieuniknione polemiki”. Taki dialog bardzo by mnie ucieszył, rozumiem bowiem doskonale, że moja książka nie jest z pewnością ostatnim słowem na temat tych delikatnych i bolesnych kwestii. 